\title{
Money Demand in Rwanda: A Cointegration Analysis 2008Q3-2015Q4
}

\author{
Fabrice Nkurunziza \\ Statistics Applied to Economy Department, \\ INES-Ruhengeri, P.O. Box, 155, Musanze/Rwanda \\ Tel: 250-781-267-277_E-mail: nkurufabre123@ines.ac.rw
}

Received: October 3, 2016 Accepted: November 16, 2015 Published: December 23, 2016

doi:10.5296/ieb.v2i2.10497

URL: http://dx.doi.org/10.5296/ieb.v2i2.10497

\begin{abstract}
This paper estimates the demand for money in Rwanda over the 2008Q3 to 2015Q4 period via unit root and cointegration methods. Utilizing the Johansen cointegration methodology, it establishes that a long-term relationship exists among the included variables. The paper also estimates an error correction model (ECM) as well as a vector error correction model (VECM), extending previous analyses by testing for Granger causality among the variables. It finds that the narrow definition of money, M1, serves as a relatively better measure of the money aggregate than M2, and M3. The long-term interest rate (LKRR) also seems to provide relatively better results than the short-term rate (LRR, and LTR) when we use broad money definition, M2. Both the ECM and VECM for M1, narrow definition of money estimates showed the expected signs, in the ECM model as expected LM1 and LGDP were positively related while LM1 and LKRR, LRR, and LTR were negatively related. The adjustment coefficient in the ECM showed that about $79.75 \%$ of disequilibrium is corrected in each quarter. Impulse response functions suggest that the traditional money demand function, which places LM1 as its 'dependent' variable while including income and interest rates as its regressors, was stable with little responses in the specific case of Rwanda over the period under review.
\end{abstract}

Keywords: Error correction model (ECM), Granger Causality test, Johansen cointegration test, Money demand function (M1, M2 and M3), Breusch-Godfrey Serial Correlation LM test, Rwanda 


\section{Introduction}

The existence of a stable demand function for Money in any economy is important for the conduct of monetary policy and financial analysis. However, despite much research into the subject in many countries, mostly developed-US and emerging economies-Korea, there is no much research in developing economies like Rwanda.

Money is necessary in order to carry out transactions. However inherent to the holding of money is the trade-off between the liquidity advantage of holding money and the interest advantage of holding other assets this leads to the definition of interest rate as given by Keynes (1939) interest rate is "the 'price' which equilibrates the desire to hold wealth in the form of cash with the available quantity of cash."

The central bank's monetary policy and goals are often depends on its knowledge and stability of money demand, since any change in money supply can turn fruitless if it does not take into consideration of the demand side (Hyungsun \& Miguel, 2016). When the demand for money is stable, monetary policy can help to stabilize an economy. However, when the demand for money is not stable, real and nominal interest rates will change and there will be economic fluctuations.

In economics, the demand for money is the desired holding of financial assets in the form of money. The nominal demand for money generally increases with the level of nominal output (the price level multiplied by real output). The interest rate is the price of money. The quantity of money demanded increases and decreases with the fluctuation of the interest rate. The real demand for money is defined as the nominal amount of money demanded divided by the price level. Money demand and supply in Rwanda remains under objectives of central bank of Rwanda-BNR (Banque nationale du Rwanda)

The objective of monetary policy in Rwanda remains to deliver price stability. More generally, BNR uses open market operations (OMOs) to implement its monetary policy. For the purpose of review, only repo, treasury bills are taken into considerations based on the fact that they are active instruments. There exist other instruments such as reserve requirement, discount window, lending facility and deposit facility and from time to time the foreign exchange interventions (BNR, 2015). More recent studies, however, tried to distinguish the short-run effects of monetary uncertainty from its long-run effects, to establish the determinants of money demand in economy, and to test volatility in monetary growth using different approaches such Keynes approach, Milton Friedman volatility hypothesis....

In this Paper we have tried to Introduce and understand the demand for money in Rwanda. To that end we briefly review studies pertaining to the demand for money in mostly developing and emerging economies in section II and introduce the model and the method in Section III. Empirical results in Section IV. Finally, Section IV concludes.

\section{Literature Review}

For Rwanda, there is no much literature about the subject; the reference is made to researches mostly conducted in other countries, in recent paper written by Hyungsun \& Miguel (2016) 
about money demand in Korea, found that $\mathrm{M}_{2}$, the broad definition of money, serve as the relatively better measure of the money aggregate than $\mathrm{M}_{1}$, and that there is a long-run relationship among real money aggregates, real income as measured as real GDP, and short-and long-run interest rate. In study panel on selected OECD Countries (Kumar et al., 2013), founds cointegration using $\mathrm{M}_{1}$, and the demand stays stable even during financial reforms if structural changes are allowed. Saten Kumar et al. (2008) conducted study on Nigeria for a period of 1960-2008, found that canonical specification of the money demand performs better for the Nigerian economy and the results suggested that there is a cointegrating relationship between real narrow money, real income and the nominal rate of interest after allowing for a structural break and their findings imply that Nigeria could effectively use the supply of money as an instrument of monetary policy. Bahmani-Oskooee et al. (2012) tested the hypothesis using Chinese data; they found that monetary uncertainty had only short-run positive effects on the demand for money in China that did not last into the long run. Bahmani-Oskooee and Bohl (2000) estimated the demand for money for the unified Germany showed that cointegration among a set of variables does not necessarily imply a stable function. One must apply statistical tests for the stability of long-run as well as short-run estimated elasticities to determine whether they are stable over time.

\section{The Money Demand Function and Estimation Method}

\subsection{The Money Demand Function}

Monetarist assumes that the demand for real money balances is a function primarily of a few economic variables including income, as a proxy of total wealth, and the interest rate, as a measure of the opportunity cost of holding money.

According to the simplest Cambridge version of quantity theory of money (Dwivedi, 2010), demand for money $\left(\mathrm{M}^{\mathrm{d}}\right)$ is a function of proportion of money income held as currency and bank deposits $(k)$, Price $(\mathrm{P})$ and Real income (Y or Q)

$$
\mathrm{M}^{\mathrm{d}}=k \mathrm{PQ}
$$

And according to the Keynesian theory of demand for money (ibid), demand for money $\left(\mathrm{M}_{\mathrm{d}}\right)$ is a function of proportion of money income held as currency and bank deposits $(k)$, Real income(Y) and Interest rate (i)

$$
\mathrm{M}_{\mathrm{d}}=k \mathrm{Y}+f(\mathrm{i})
$$

And the Keynesian demand for money function has been adopted by many researches, Hwang (2002), Hyungsun \& Miguel (January 2016), Monet \& Weber (2001) and is the same function we have adopted in this research.

The literature suggests that the demand for real money balances, $M t$, depends positively on real income $Y t$ and negatively on the nominal interest rate, $R$. The expectation of a positive relationship between money and income is reasonable: as people get wealthier, they demand more money for transactions purposes. For the interest rate, this paper assumes the traditional liquidity preference-money supply (LM) function, and consequently the working of a "liquidity effect in the economy. In other words, as the interest rate increases, the 
"opportunity cost of holding cash" also increases and the demand for money decreases (Monnet and Weber, 2001). Certainly, there are more variables that are often included in the money demand function in the literature. The exchange rate is an example. Still, this paper only focuses on the two traditional determinants of real money demand in Rwanda.

\subsection{Data and Variables}

We employed three different real measures of money demand, $\mathrm{M}_{1}, \mathrm{M}_{2}$, and $\mathrm{M}_{3}$ in order to determine more appropriate alternative. Because it is hard to judge which assets should be included in the money stock, various measures are available, there are four measures as defined by Federal reserve and adopted by many central banks such as central bank of Rwanda-BNR, with a little change. The four measures of stock of money as defined by Federal Reserve (Mankiw, 2007), C stand for currency in circulation, $M_{1}$ which includes Currency plus demand deposits, Traveller's checks, and other checkable deposits, $M_{2}$ which includes $M_{1}$ plus retail money market mutual fund balances, saving deposits (including money market deposit accounts), and small time deposits. Then $M_{3}$ which includes $M_{2}$ plus large time deposits, repurchase agreements, Eurodollars, and institution-only money market mutual fund balances. And BNR defines $M_{1}$ as narrow money which includes currency in circulation plus deposits of which includes transferable deposits in Frw, non-transferable deposits Frw, and foreign currency deposits, $M_{2}$ as the currency in circulation, demand, time and savings deposits. The deposits are held by the private sector and exclude those held by the central government, $M_{2} \mathrm{~A}$ this is equivalent to $M_{2}$ plus certificates of deposits, and $M_{3}$ as equivalent to $M_{2} \mathrm{~A}$ plus foreign currency deposits (RSYB, 2013).All these three measures used in this research, are measured in national currency, Francs Rwandais, Income is measured using real gross domestic product (GDP), also in National Currency, Natural logarithms of real money aggregates and GDP, denoted by $L M_{1}, L M_{2}, L M_{3}$ and $L \mathrm{GDP}$, are used in order to control for potential outliers in the distribution and to make the calculation of income elasticity easier. Such logarithmic transformation of macroeconomic variables is a common procedure in the literature.

As for the interest rate, the paper considered only money market rate such as Repo and Treasure bill rate since are only active instruments in Rwanda (BNR, Quarterly Monetary Report, 2015) both Repo and Treasure rates are short-term interests rate, each denoted as $R R$ and $T R$, respectively, and for long term interest rate we have considered Key repo rate denoted by KRR (Note 1), we have considered data from 2008Q3 due to the reason that Repo rate was introduced in Rwanda in august 2008 (BNR, 2008). Thus, three models were estimated:

$$
\begin{aligned}
& \log M_{1}=\alpha_{0}+\alpha_{1} \log \mathrm{GDP}+\alpha_{2} \mathrm{KRR}+\alpha_{3} R R+\alpha_{4} T R+\varepsilon_{\mathrm{t}} \\
& \log M_{2}=\alpha_{0}+\alpha_{1} \log \mathrm{GDP}+\alpha_{2} \mathrm{~K} R R+\alpha_{3} R R+\alpha_{4} T R+\varepsilon_{\mathrm{t}} \\
& \log M_{3}=\alpha_{0}+\alpha_{1} \log \mathrm{GDP}+\alpha_{2} \mathrm{~K} R R+\alpha_{3} R R+\alpha_{4} T R+\varepsilon_{\mathrm{t}}
\end{aligned}
$$

The data for all variables, for the period 2004Q1 to 2015Q2, Except Real GDP where Data were obtained from NISR reports, for other variables data were obtained from monetary survey, monetary policy and statements, and BNR economic review, all these documents 
were published by BNR.

\section{Empirical Results and Discussion}

\subsection{Unit Roots Analysis}

Prior to testing for cointegration, all variables were tested for unit roots. Most macroeconomic variables tend to exhibit deterministic and/or stochastic trends over time, which can be problematic especially when they are shared among variables that have no economic relationship. It is possible that spurious regressions will show inflated t-statistics and F-statistics, leading to incorrect conclusions. Thus, in a time series analysis, stationarity must be confirmed; or, in the case of non-stationarity, appropriate methodologies must be applied to correct for it (Engle \& Granger, 1987).

The augmented Dickey-Fuller (ADF) test and the Phillips-Perron (PP) test, which are the two conventional tests in the literature, were implemented. The PP test takes into account "the less restrictive nature of the error process (Asteriou \& Hall, 2011) by taking a non-parametric approach, or not assuming that the distribution of the error term is known and normally distributed. The PP test is therefore considered to be more 'powerful accordingly, 'If the ADF and PP tests show conflicting results, we will defer to the PP statistics to determine the existence of unit roots.

In case of The augmented Dickey-Fuller (ADF) test, there may create a problem of autocorrelation, to tackle the problem of autocorrelation Dickey have developed a test called augmented Dickey-Fuller (ADF) test stated below (equation 6, 7 and 8)

$$
\begin{gathered}
\Delta Y_{t}=\beta_{1}+Z Y_{t-1}+a_{i}+e_{t} \text { (Intercept only) } \\
\Delta Y_{t}=\beta_{1}+\beta_{2} t+Z Y_{t-1}+a_{i}+e_{t} \text { (Trend and Intercept) } \\
\Delta Y_{t}=Z Y_{t-1}+a_{i}+e_{t} \text { (No trend, No Intercept) }
\end{gathered}
$$

The null hypothesis in both tests is the presence of a unit root, or non-stationarity. The alternative is that of no unit root, or stationarity.

Among these three possible model specifications stated above that can be used for unit root tests. To determine the most appropriate one, this paper followed the procedure developed by Doldado et al. (1990). The ADF and PP tests are performed first using the most general model which contains both constant and a deterministic trend. If the coefficients of the two trend elements are not significant, it proceeds to test with only the constant. If the coefficient of the constant is still insignificant, the model with neither element was used to test for unit roots. As shown in Table 1, this paper finds evidence for non-stationarity in most variables in level form using the ADF and PP test, And in first differenced form all variables were found to be stationary at 5\% level of significance except LKRR and LTR which are stationary at $10 \%$ level of significance, suggesting that variables in this sample are integrated of order one. 
Table 1. Unit root test results

\begin{tabular}{|c|c|c|c|c|c|c|c|}
\hline \multirow{2}{*}{ Variable } & \multicolumn{2}{|c|}{ Test Statistics } & \multicolumn{3}{|c|}{ Level of Significance } & \multirow{2}{*}{ Eq. used } & \multirow{2}{*}{ Decision } \\
\hline & ADF & $\mathbf{P P}$ & $1 \%$ & $5 \%$ & $10 \%$ & & \\
\hline $\mathrm{D}(\mathrm{LGDP})$ & -7.112285 & -6.650744 & $-4.3382 *$ & $-3.5867^{*}$ & $-3.2279^{*}$ & Eq. 4.2 & $\mathrm{~S}$ \\
\hline $\mathrm{D}(\mathrm{LM} 1)$ & -4.221796 & -6.650744 & -4.3382 & $-3.5867^{*}$ & $-3.2279^{*}$ & Eq. 4.2 & $\mathrm{~S}$ \\
\hline $\mathrm{D}(\mathrm{LM} 2)$ & -4.042419 & -6.650744 & -4.3382 & $-3.5867^{*}$ & $-3.2279 *$ & Eq. 4.2 & S \\
\hline $\mathrm{D}(\mathrm{LM} 3)$ & -4.017220 & -9.068355 & -4.3382 & $-3.5867^{*}$ & $-3.2279^{*}$ & Eq. 4.2 & $\mathrm{~S}$ \\
\hline D(LKRR) & -3.409525 & -4.533941 & -4.3382 & -3.5867 & $-3.2279 *$ & Eq. 4.2 & S \\
\hline $\mathrm{D}(\mathrm{LRR})$ & -3.895065 & -4.219525 & -4.3382 & $-3.5867^{*}$ & $-3.2279 *$ & Eq. 4.2 & S \\
\hline $\mathrm{D}(\mathrm{LTR})$ & -3.360776 & -4.608556 & -4.3382 & -3.5867 & $-3.2279 *$ & Eq. 4.2 & $\mathrm{~S}$ \\
\hline D(LKRR) & -3.391567 & -4.661889 & $-2.6522 *$ & $-1.9540^{*}$ & $-1.6223^{*}$ & Eq. 4.3 & $\mathrm{~S}$ \\
\hline $\mathrm{D}(\mathrm{LTR})$ & -3.431061 & -4.843852 & $-2.6522 *$ & $-1.9540 *$ & $-1.6223^{*}$ & Eq. 4.3 & S \\
\hline
\end{tabular}

Note. S: Stationarity, *: stationarity at that level where the coefficients of the two trend elements are significant.

\subsection{Cointegration Analysis}

Since all variables appear to contain unit roots in their level form, we proceed to test for cointegration, or the existence of a long-run equilibrium relationship. Residuals of the ordinary least-squares (OLS) estimations were shown to be stationary in the ADF and PP tests, indicating the presence of a cointegrating relationship (Note 2). However, the simple Engle-Granger (EG) approach, although suggestive, does not provide very reliable results for cointegration in equation (1) for several reasons. First, since the equation includes more than two variables, there may be more than one cointegrating relationship. The EG test cannot account for this possibility, and might induce specification errors. Second, the test uses the money aggregate as the 'dependent' variable and other variables as regressors, without considering a different ordering -for instance, LGDP could be placed on the left-hand side instead of LM1, Lastly, it is a two-step process that involves the generation of residuals, first, and test for unit roots, second. In such a process, errors from the first step can be carried over to the next step (Asteriou \& Hall, 2011).

So instead, we utilize the Johansen (1990) methodology, which uses a multiple-equation method to determine the number of maximum cointegrating vectors (n-1).

$\mathrm{H}_{0}$ : there is no cointegration among variables

$\mathrm{H}_{1}$ : there is cointegration among variables

To determine the appropriate number of lags, the paper first estimated a regular vector autoregressive (VAR) models, starting with a leg length of eight and then compare the maximum number of lags length predicted by each test considered, Sequential modified LR test, Final predictor error (FPE), Akaike information criterion (AIC), Schwarz information criterion (SC) and Hannan-quinn information criterion (HQ) and two was determined to be the optimal length of lag as predicted by majority of test used may be the reason can be less number of observations. Having established the lag length, we proceeded by checking if the three models are cointegrated and number of cointegrated equations, in model 3.3 there are at most three cointegrating vectors, in model 3.4 there are at most three cointegrating vectors, and in Model 3.5 there are at most two cointegrating vectors, in other words, a long-run 
equilibrium relationship among the money aggregates (M1, M2 and M3) and its determinants (GDP,KRR,RR and TR) exist for the case of Rwanda, which is an important finding in the literature and we proceeded by running ECM .

Table 2. Johansen Test Results

Date: $05 / 27 / 16$ Time: $15: 32$

Sample: 2008Q3 2015Q4

Included observations: 27

Test assumption: Linear deterministic trend in the data

Series: LM1 LGDP LKRR LTR LRR

Lags interval: 1 to 2

\begin{tabular}{lllll}
\hline Eigenvalue & $\begin{array}{l}\text { Likelihood } \\
\text { Ratio }\end{array}$ & $\begin{array}{l}\text { 5 Percent } \\
\text { Critical Value }\end{array}$ & $\begin{array}{l}\text { 1 Percent } \\
\text { Critical Value }\end{array}$ & $\begin{array}{l}\text { Hypothesized } \\
\text { No. of CE(s) }\end{array}$ \\
\hline 0.815037 & 116.5841 & 68.52 & 76.07 & None ** \\
0.761323 & 71.01887 & 47.21 & 54.46 & At most $1 * *$ \\
0.485000 & 32.33746 & 29.68 & 35.65 & At most $2 *$ \\
0.289092 & 14.42055 & 15.41 & 20.04 & At most 3 \\
0.175421 & 5.207812 & 3.76 & 6.65 & At most 4 \\
\hline
\end{tabular}

*(**) denotes rejection of the hypothesis at 5\% (1\%) significance level. L.R. test indicates 3 cointegrating equation(s) at 5\% significance level.

Table 3

Date: 05/27/16 Time: 15:34

Sample: 2008Q3 2015Q4

Included observations: 27

Test assumption: Linear deterministic trend in the data

Series: LM2 LGDP LKRR LTR LRR

Lags interval: 1 to 2

\begin{tabular}{lllll}
\hline Eigenvalue & $\begin{array}{l}\text { Likelihood } \\
\text { Ratio }\end{array}$ & $\begin{array}{l}\text { 5 Percent } \\
\text { Critical Value }\end{array}$ & $\begin{array}{l}\text { 1 Percent } \\
\text { Critical Value }\end{array}$ & $\begin{array}{l}\text { Hypothesized } \\
\text { No. of CE(s) }\end{array}$ \\
\hline 0.891356 & 114.5709 & 68.52 & 76.07 & None ** \\
0.554716 & 54.63954 & 47.21 & 54.46 & At most $1 * *$ \\
0.490496 & 32.79539 & 29.68 & 35.65 & At most $2 *$ \\
0.296600 & 14.58884 & 15.41 & 20.04 & At most 3 \\
\hline
\end{tabular}




\begin{tabular}{lllll}
\hline 0.171798 & 5.089438 & 3.76 & 6.65 & At most $4 *$
\end{tabular}

$*(* *)$ denotes rejection of the hypothesis at $5 \%(1 \%)$ significance level. L.R. test indicates 3 cointegrating equation(s) at $5 \%$ significance level.

Table 4.

Date: 05/27/16 Time: 15:41

Sample: 2008Q3 2015Q4

Included observations: 27

Test assumption: Linear deterministic trend in the data

Series: LM3 LGDP LKRR LTR LRR

Lags interval: 1 to 2

\begin{tabular}{lllll}
\hline Eigenvalue & $\begin{array}{l}\text { Likelihood } \\
\text { Ratio }\end{array}$ & $\begin{array}{l}\text { 5 Percent } \\
\text { Critical Value }\end{array}$ & $\begin{array}{l}\text { 1 Percent } \\
\text { Critical Value }\end{array}$ & $\begin{array}{l}\text { Hypothesized } \\
\text { No. of CE(s) }\end{array}$ \\
\hline 0.783152 & 93.82798 & 68.52 & 76.07 & None** \\
0.576249 & 52.55684 & 47.21 & 54.46 & At most $1^{*}$ \\
0.469993 & 29.37437 & 29.68 & 35.65 & At most 2 \\
0.326170 & 12.23302 & 15.41 & 20.04 & At most 3 \\
0.056631 & 1.574033 & 3.76 & 6.65 & At most 4 \\
\hline
\end{tabular}

$*(* *)$ denotes rejection of the hypothesis at $5 \%(1 \%)$ significance level. L.R. test indicates 3 cointegrating equation(s) at 5\% significance level.

\subsection{Error Correction Model (ECM)}

In order to "reconcile the short-run dynamics to the long-run relationship," an ECM was first estimated for each group of variables. The ECM, usually utilized for cointegrated $I(1)$ series, differences the data to capture the short-run relationships and also includes the lagged residual terms as regressors to capture the long-run effects (Asteriou \& Hall, 2011). The ECMs are mathematically represented as:

$$
\begin{aligned}
& \Delta \log M_{1}=\alpha_{0}+\alpha_{1} \log \Delta \mathrm{GDP}+\alpha_{2} \Delta \mathrm{K} R R+\alpha_{3} \Delta R R+\alpha_{4} \Delta T R+\alpha_{5} \varepsilon_{t-1}+\mathrm{U}_{\mathrm{t}} \\
& \Delta \log M_{2}=\alpha_{0}+\alpha_{1} \log \Delta \mathrm{GDP}+\alpha_{2} \Delta \mathrm{K} R R+\alpha_{3} \Delta R R+\alpha_{4} \Delta T R+\alpha_{5} \varepsilon_{t-1}+\mathrm{U}_{\mathrm{t}} \\
& \Delta \log M_{3}=\alpha_{0}+\alpha_{1} \log \Delta \mathrm{GDP}+\alpha_{2} \Delta \mathrm{K} R R+\alpha_{3} \Delta R R+\alpha_{4} \Delta T R+\alpha_{5} \varepsilon_{t-1}+\mathrm{U}_{\mathrm{t}}
\end{aligned}
$$

$\mathrm{U}_{\mathrm{t}}$ is white noise error term, $\varepsilon_{t-1}$ is the one period lag residual of model 8,9 and $10, \varepsilon_{t-1}$ is also known as equilibrium error term of one period lag. This $\varepsilon_{t-1}$ is an error correction term 
that guides the variables $\left(\mathrm{M}_{1}, \mathrm{M}_{2}, \mathrm{M}_{3}\right.$, GDP, KRR, RR, and TR) of the system to restore back to equilibrium. In other words it corrects disequilibrium. The sign before $\alpha_{5}$ is the sign of error correction term and should be negative after estimation; the coefficient $\alpha_{5}$ tell us at what rate it corrects the previous period disequilibrium of the system, when $\alpha_{5}$ is significant and contains negative sign, it validates that there exists a long run equilibrium relationship among variables $\left(\mathrm{M}_{1}, \mathrm{M}_{2}, \mathrm{M}_{3}, \mathrm{GDP}, \mathrm{KRR}, \mathrm{RR}\right.$, and TR) stated in model 8, 9 and $10, \alpha_{0}$ is the intercept in each model $\alpha_{1}, \alpha_{2}, \alpha_{3} \alpha_{4}$ represents the short run coefficients in each model.

Estimated equations are:

$$
\begin{gathered}
\mathrm{D}\left(\mathrm{LM}_{1}\right)=0.01977571481+1.098337796 * \mathrm{D}(\mathrm{LGDP})-0.1405363214 * \mathrm{D}(\mathrm{LKRR})+ \\
0.05180929494 * \mathrm{D}(\mathrm{LRR})-0.09290582213 * \mathrm{D}(\mathrm{LTR})-0.797590502 * \mathrm{E}(-1) \\
\mathrm{D}\left(\mathrm{LM}_{2}\right)=0.03427747783+0.2651393793 * \mathrm{D}(\mathrm{LGDP})-0.3981283671 * \mathrm{D}(\mathrm{LKRR})+ \\
0.07949116812 * \mathrm{D}(\mathrm{LRR})-0.1756576946 * \mathrm{E}(-1) \\
\mathrm{D}\left(\mathrm{LM}_{3}\right)=0.0402288333+0.2435369716 * \mathrm{D}(\mathrm{LGDP})-0.1660090452 * \mathrm{D}(\mathrm{LKRR})+ \\
0.108747466 * \mathrm{D}(\mathrm{LRR})-0.1141161111 * \mathrm{D}(\mathrm{LTR})-0.1492663026 * \mathrm{E}(-1)
\end{gathered}
$$

The estimates are shown in Table 5. The coefficients for LGDP, LKRR, LRR and LTR have signs that are expected and consistent with the economic relationship discussed in the third section except for LRR in 12 and 13 models. The adjusted R-sq. terms are reasonable for this type of differenced model and the F-stats suggest that the model as a whole are highly significant in explaining the variation in the real money aggregates only in model 12 , while in model 13 and $14 \mathrm{~F}$-stats are statistically insignificant. R-squared in model 12 suggest that change in narrow money $\left(\mathrm{M}_{1}\right)$ is explained buy GDP, KRR, RR and TR by $46 \%$, by using Akaike info criterion we found out that model 12 is better than others, all models are non-spurious models since their R-squared are lower than Durbin-Watson stat value and their residuals are stationary, In this model $\mathrm{DLM}_{1}$, the long-run income elasticity of money demand is estimated to be 1.098338. In other words, a ceteris paribus one percent change in GDP will induce $\mathrm{M}_{1}$ to increase by 109.8 percent. the sign of $\mathrm{E}(-1)$ for only model 12 was found to be negative and significant indicating the validity of long run equilibrium relationship between $\mathrm{M}_{1}$, GDP, KRR, RR and TR, the coefficient of error term has been $79.75 \%$, meaning that the system corrects its previous period dis-equilibrium at a speed of $79.75 \%$ quarterly.

Table 5. Error correction model

\begin{tabular}{lccc}
\hline & D(LM1) & D(LM2) & D(LM3) \\
\hline C & 0.019776 & 0.034277 & 0.040229 \\
D(LGDP) & $1.098338^{*}$ & 0.265139 & 0.243537 \\
D(LKRR) & -0.140536 & $-0.398128^{*}$ & -0.166009 \\
D(LRR) & 0.051809 & 0.079491 & -0.166009 \\
D(LTR) & -0.092906 & -0.175658 & 0.108747 \\
E(-1) & $-0.797591^{*}$ & -0.175658 & -0.114116 \\
\hline
\end{tabular}




\begin{tabular}{lccc}
\hline R-squared & 0.467664 & 0.237103 & 0.248891 \\
Adjusted R-squared & 0.351939 & 0.109954 & 0.085607 \\
Durbin-Watson stat & 2.307807 & 2.555224 & 2.719584 \\
F-statistic & $4.041164 *$ & 1.864759 & 1.524279 \\
AIC & -2.213554 & -2.561127 & -2.988395 \\
\hline
\end{tabular}

Note. t-statistics can be checked in tables from appendix. *denotes significance at the $5 \%$ level.

\subsection{Residual Tests}

\subsubsection{Normality Test}

Normality is a condition in which the variables to be used in the model follow the standard normal distribution, The Jarque-Bera statistics is used to test the normality of the variable under different conditions and hypotheses;

$\mathrm{H}_{0}$ : The residual is normally distributed

$\mathrm{H}_{1}$ : The residual is not normally distributed

If the residual is normally distributed, the histogram should be bell shaped and the Jarque-Bera statistic insignificant. It thus follows that series will be normally distributed at $5 \%$ level of significance if the probability of J-B statistic is greater than 0.05 .

$$
I B=\pi\left[\frac{s^{2}}{6}+\frac{(K-3)^{2}}{24}\right]
$$

(Where n: Sample size, S: Skewness coefficient, and K: Kurtosis coefficient).

Residuals were found to be normal distributed in all three models, see Table 6 .

\subsubsection{Autocorrelation Test}

Autocorrelation may be defined as a correlation between members of series of observations ordered in time [as in time series data] or space [as in cross-sectional data]. When the error in one time period is positively correlated with the error term in the previous time period, we face the problem of (positive order) correlation. But this is very common in time series analysis and this leads to downward-biased standard errors (and, thus to incorrect statistical tests and confidence intervals). In the regression context, the classical linear regression model assumes that such autocorrelation does not exist in the disturbance $u_{i}$.

$$
\text { Symbolically E }\left(u_{i}, u_{j}\right)=0 \quad t \neq t
$$

Simply, the classical model assumes that the disturbance term relating to any observation is not influenced by disturbance term relating to any observation. So the presence of autocorrelation was tested by using the Breusch-Godfrey LM test.

$\mathrm{H}_{0}$ : The residual is not serial correlated 
$\mathrm{H}_{1}$ : The residual is not serial correlated

Then from Breusch-Godfrey LM test results models 4.8 and 4.9 residuals were found not to be serial correlated while in 4.10 residuals were found to be serial correlated. See Table 6.

\subsubsection{Heteroskedasticity}

This term will be used to describe the situation when the variance of the residuals from a model is not constant and then OLS is not an appropriate method to estimate the coefficients and the appropriate method is generalized least squares (GLS). When its variance is constant, we call it homoskedasticity and OLS is applicable. For testing Heteroskedasticity, we will use Breusch-Pagan-Godfrey test, with null hypothesis that the variance of residual $(u)$ is constant against the alternative that the variance of residual $(u)$ is not constant.

The Breusch-Pagan-Godfrey test is given by

$$
F^{\prime \prime}=\frac{\left[R^{n} / k k\right]}{\left[\left(1-E^{2}\right) /(n-k-1)\right]} \sim F_{k m-k-1}^{\prime \prime}
$$

$\mathrm{H}_{0}$ : there is no Heteroskedasticity in residuals

$\mathrm{H}_{1}$ : there is Heteroskedasticity in residuals

Then from White Heteroskedasticity test results, all models: 12, 13 and 14 were found not to suffer from Heteroskedasticity. See Table 6

Table 6. Residual test result

\begin{tabular}{llll}
\hline & $\begin{array}{l}\text { J.B Statistics } \\
\text { (Normality) }\end{array}$ & $\begin{array}{l}\text { Breusch-Godfrey } \\
\text { correlation LM test }\end{array}$ & $\begin{array}{l}\text { White } \\
\text { Heteroskedasticity test }\end{array}$ \\
\hline D(LM1) & 0.867934 & 0.215428 & 0.161457 \\
D(LM2) & 0.740882 & 0.133792 & 0.947026 \\
D(LM3) & 0.768125 & 0.033817 & 0.871726 \\
\hline
\end{tabular}

Note. the value in table denotes the probability.

\subsection{Vector Error Correction Model (VECM)}

Next, a VECM is estimated because it addresses the drawbacks of the popular EG approach which were previously discussed, and have both information about short and long run adjustments. The VECM framework will treat all variables in the money demand function as endogenous; instead of assuming exogeneity based on the standard theory (Ramirez \& Komuves, 2014).

It was suggested before that the direction of causality might run from the regressors to M1, M2 or M3 or from one regressor to another. The VECM, by transforming the single-equation ECM to a multivariate one, controls for this potential endogeneity (Asteriou \& Hall, 2011).

Johansen-juselius multivariate cointegration model is given below: 


$$
\Delta X_{t}=\sum_{i=1}^{t} \Gamma_{i} \Delta X_{t-1}+\Pi X_{t-1}+\varepsilon_{t}
$$

Where $X_{t}$ is the $2 \times 1$ vector $\left(\mathrm{M}_{1}, \mathrm{M}_{2}, \mathrm{M}_{3}\right.$, GDP, KRR, RR, and TR) respectively, $\Delta$ is a symbol of difference operator, $\varepsilon_{t}$ is a $2 \times 1$ vector of residuals, VECM model has information about the short and long run adjustments to changes in $X_{t}$, via the estimated parameters $\Gamma_{i}$ and $\Pi$ respectively. Here, the expression $\Pi X_{t-1}$ is the error correction term and $\Pi$ can be factored into two separate matrices $\alpha$ and $\beta$, such as $\Pi=\alpha \beta$. Where $\beta$ denotes the vector of cointegrating parameters while $\alpha$ is the vector error-correction coefficients measuring the speed of convergence to the long-run steady state.

As $\mathrm{M}_{1}$, GDP, KRR, RR, and TR are cointegrated, an EVCM representation have the following form:

$$
\begin{aligned}
& \Delta \mathrm{LM}_{1_{t}}=\sum_{i=1}^{t} \alpha_{1} \Delta \mathrm{LGDP}_{t-1}+\sum_{i=1}^{t} \alpha_{2} \Delta \mathrm{LKRR}_{t-1}+\sum_{i=1}^{t} \alpha_{3} \Delta \mathrm{LRR}_{t-1}+\sum_{i=1}^{t} \alpha_{4} \Delta \mathrm{LTR}_{t-1}+ \\
& \alpha_{5} \varepsilon_{t-1}+\mathrm{U}_{\mathrm{t}} \\
& \Delta \mathrm{LGDP}_{t}=\sum_{i=1}^{t} \alpha_{1} \Delta \mathrm{LM}_{1_{t-1}}+\sum_{i=1}^{t} \alpha_{2} \Delta \mathrm{LKRR}_{t-1}+\sum_{i=1}^{t} \alpha_{3} \Delta \mathrm{LRR}_{t-1}+\sum_{i=1}^{t} \alpha_{4} \Delta \\
& \mathrm{LTR}_{t-1}+\alpha_{5} \varepsilon_{t-1}+\mathrm{U}_{\mathrm{t}} \\
& \Delta \mathrm{LKRR}_{t}=\sum_{i=1}^{t} \alpha_{1} \Delta \mathrm{LGDP}_{t-1}+\sum_{i=1}^{t} \alpha_{2} \Delta \mathrm{LM}_{1_{t-1}}+\sum_{i=1}^{t} \alpha_{3} \Delta \mathrm{LRR}_{t-1}+\sum_{i=1}^{t} \alpha_{4} \Delta \\
& \mathrm{LTR}_{t-1}+\alpha_{5} \varepsilon_{t-1}+\mathrm{U}_{\mathrm{t}} \\
& \Delta \mathrm{LRR}_{t}=\sum_{i=1}^{t} \alpha_{1} \Delta \mathrm{LGDP}_{t-1}+\sum_{i=1}^{t} \alpha_{2} \Delta \mathrm{LKRR}_{t-1}+\sum_{i=1}^{t} \alpha_{3} \Delta \mathrm{LM}_{1-1}+\sum_{i=1}^{t} \alpha_{4} \Delta \\
& \mathrm{LTR}_{t-1}+\alpha_{5} \varepsilon_{t-1}+\mathrm{U}_{\mathrm{t}} \\
& \Delta \mathrm{LTR}_{t}=\sum_{i=1}^{t} \alpha_{1} \Delta \mathrm{LGDP}_{t-1}+\sum_{i=1}^{t} \alpha_{2} \Delta \mathrm{LKRR}_{t-1}+\sum_{i=1}^{t} \alpha_{3} \Delta \mathrm{LRR}_{t-1}+\sum_{i=1}^{t} \alpha_{4} \Delta \\
& \mathrm{LM}_{1-1}+\alpha_{5} \varepsilon_{t-1}+\mathrm{U}_{\mathrm{t}}
\end{aligned}
$$

Where, $\alpha_{1}, \alpha_{2}, \alpha_{3}$, and $\alpha_{4}$ are short run coefficient, $\alpha 5$ is error correction term, $\varepsilon_{t-1}$ is the lagged value of residuals derived from the cointegrating regression and $\mathrm{Ut}$ is residual in equation

Estimated equation is:

$$
\begin{gathered}
\mathrm{D}\left(\mathrm{LM}_{1}\right)=-0.7034778615 *\left(\mathrm{LM}_{1}(-1)-2.245242758 * \operatorname{LGDP}(-1)-0.043689014 * \operatorname{LKRR}(-1)-\right. \\
0.1946795375 * \operatorname{LRR}(-1)+0.1834699539 * \mathrm{LTR}(-1)+9.622890927)+ \\
0.1372304402 * \mathrm{D}\left(\mathrm{LM}_{1}(-1)\right)+0.4485267051 * \mathrm{D}\left(\mathrm{LM}_{1}(-2)\right)-0.6277547302 * \mathrm{D}(\operatorname{LGDP}(-1))- \\
1.110189377 * \mathrm{D}(\mathrm{LGDP}(-2))+0.1524035818 * \mathrm{D}(\operatorname{LKRR}(-1))-0.40791398 * \mathrm{D}(\operatorname{LKRR}(-2))+ \\
0.1344052682 * \mathrm{D}(\operatorname{LRR}(-1))-0.1841450974 * \mathrm{D}(\operatorname{LRR}(-2))+0.07613944202 * \mathrm{D}(\operatorname{LTR}(-1))+ \\
0.1102229747 * \mathrm{D}(\operatorname{LTR}(-2))+0.05728159605
\end{gathered}
$$

Here we have estimated only first model, 21, and the results are provided in Table 7. The VECM displays significant and expected signs of normalized coefficients. The adjustment coefficient on $\mathrm{D}\left(\mathrm{LM}_{1}\right)$ is, as suggested by economic theory, negative and significant meaning that about $70.34 \%$ of disequilibrium is corrected each quarter.

To further test for 'causal' relationship among the variables, we undertook a test for Granger causality, treating LM1 as exogenous, The pairwise test, which assumes that only 
the particular pair of variables is endogenous in the VECM, suggests that causality does run from GDP and the interest rates to M1, as well as from interest rate to income and also the other way around. (Table 8 for the results)

The impulse response function as a chock to ECVM system was used, to identify the responsiveness of the dependent variables (endogenous variables) in the EVCM system, when a chock was put to the error term such as Ut at the equation, a change in $U_{1}$ will bring change in $\mathrm{DLM}_{1}$, it will change LGDP, LKRR, LRR, LTR and $L M_{1}$ during next period, so we gave chock to the residual of the below EVCM system to see how it affects the whole model.

$$
\begin{aligned}
& \Delta \mathrm{LM}_{1_{t}}=\alpha_{1} \Delta \mathrm{LGDP}_{t-1}+\alpha_{2} \Delta \mathrm{LKRR}_{t-1}+\alpha_{3} \Delta \mathrm{LRR}_{t-1}+\alpha_{4} \Delta \mathrm{LTR}_{t-1}+\mathrm{U}_{1} \\
& \Delta \mathrm{LGDP}_{t}=\alpha_{5} \Delta \mathrm{LM}_{t-1}+\alpha_{6} \Delta \mathrm{LKRR}_{t-1}+\alpha_{7} \Delta \mathrm{LRR}_{t-1}+\alpha_{8} \Delta \mathrm{LTR}_{t-1}+\mathrm{U}_{2} \\
& \Delta \mathrm{LKRR}_{t}=\alpha_{9} \Delta \mathrm{LGDP}_{t-1}+\alpha_{10} \Delta \mathrm{LM}_{t-1}+\alpha_{11} \Delta \mathrm{LRR}_{t-1}+\alpha_{12} \Delta \mathrm{LTR}_{t-1}+\mathrm{U}_{3} \\
& \Delta \mathrm{LRR}_{t}=\alpha_{13} \Delta \mathrm{LGDP}_{t-1}+\alpha_{14} \Delta \mathrm{LKRR}_{t-1}+\alpha_{15} \Delta \mathrm{LM}_{t-1}+\alpha_{16} \Delta \mathrm{LTR}_{t-1}+\mathrm{U}_{4} \\
& \Delta \mathrm{LTR}_{t}=\alpha_{17} \Delta \mathrm{LGDP}_{t-1}+\alpha_{18} \Delta \mathrm{LKRR}_{t-1}+\alpha_{19} \Delta \mathrm{LR}_{t-1}+\alpha_{20} \Delta \mathrm{LM}_{t-1}+\mathrm{U}_{5}
\end{aligned}
$$

The results of impulse function (see Figure 1), when we have given one standard deviation positive shock to LGDP, $\mathrm{LM}_{1}$ first increased in first quarter, then decreased in fourth quarter but remained positive, while one standard deviation positive shock to LRR, LKRR was zero in first quarter and becomes negative in remaining three quarters, and one standard deviation positive shock to LKRR, LRR was negative in first quarter then becomes positive, responses of LKRR to LTR or LTR to LKRR, the variable fluctuated positively in case of response of LTR to LKRR, and negatively in case of LKRR to LTR.

\subsubsection{Cointegration Coefficients}

Table 7. Vector Error Correction Model (for DLM1)

\begin{tabular}{ccccccc}
\hline & $\mathrm{D}(\mathrm{LM} 1)$ & $\mathrm{D}(\mathrm{LGDP})$ & $\mathrm{D}(\mathrm{LKRR})$ & $\mathrm{D}(\mathrm{LRR})$ & $\mathrm{D}(\mathrm{RT})$ & $\mathrm{C}$ \\
\hline \multirow{4}{*}{$(-1)$} & & -0.627755 & 0.152404 & 0.134405 & 0.076139 & 0.057282 \\
& & & & \\
& & $(0.85327)$ & $(0.31460)$ & $(0.14582)$ & $(0.14890)$ & $(0.02889)$ \\
$(-2)$ & & $(-0.73570)$ & $(0.48443)$ & $(0.92172)$ & $(0.51133)$ & $(1.98258)$ \\
& & -1.110189 & -0.407914 & -0.184145 & 0.110223 & \\
& & $(0.73604)$ & $(0.34611)$ & $(0.18559)$ & $(0.14101)$ & \\
\hline
\end{tabular}




\section{Macrothink}

Table 8. Granger causality results

\begin{tabular}{lcc}
\hline Null Hypothesis: & F-Statistic & Probability \\
\hline LGDP does not Granger Cause LM1 & 0.74864 & 0.48419 \\
LM1 does not Granger Cause LGDP & 3.13682 & 0.06243 \\
LKRR does not Granger Cause LM1 & 0.49002 & 0.61887 \\
LM1 does not Granger Cause LKRR & 0.49788 & 0.61422 \\
LRR does not Granger Cause LM1 & 3.32336 & 0.05397 \\
LM1 does not Granger Cause LRR & 1.36663 & 0.27490 \\
LTR does not Granger Cause LM1 & 0.65633 & 0.52820 \\
LM1 does not Granger Cause LTR & 0.14767 & 0.86353 \\
\hline
\end{tabular}
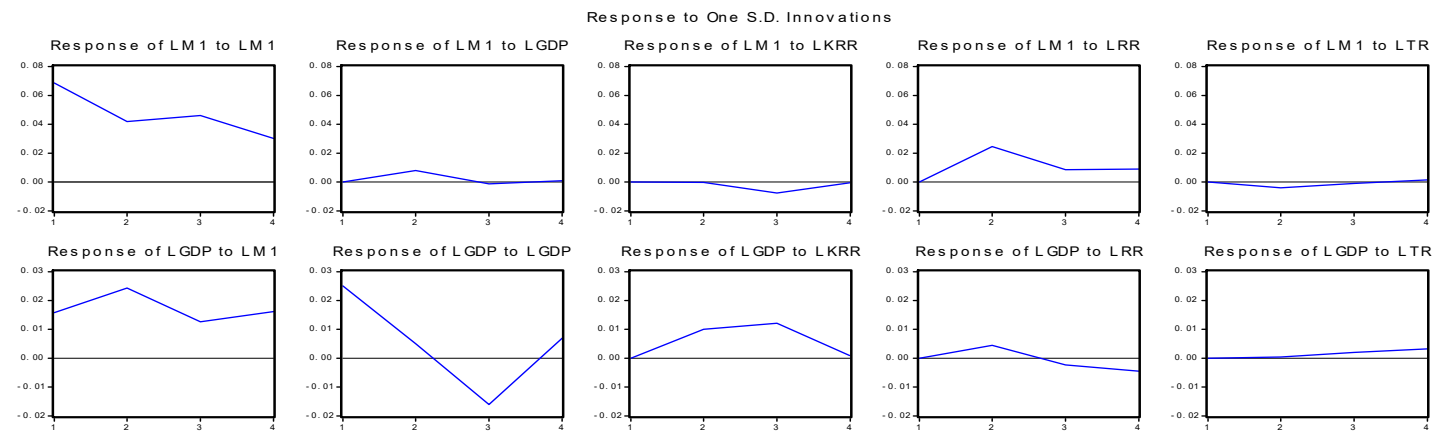

Response of LGDP to LRR

Response of LGDP to LTR
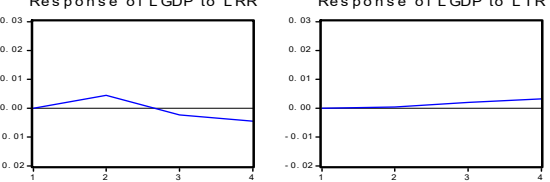

Response of LKRR to LM

Response of LKRR to LGDP
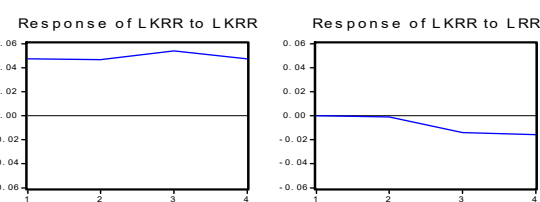

Response of LKRR to LTR
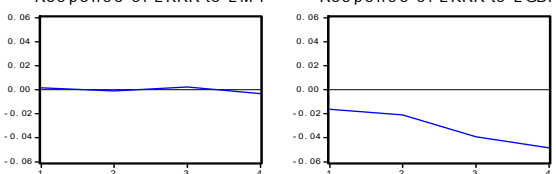

Response of LRR to LM 1

Response of LRR to LGDP

Response of LRR to LKRR

Response of $L R R$ to $L R R$
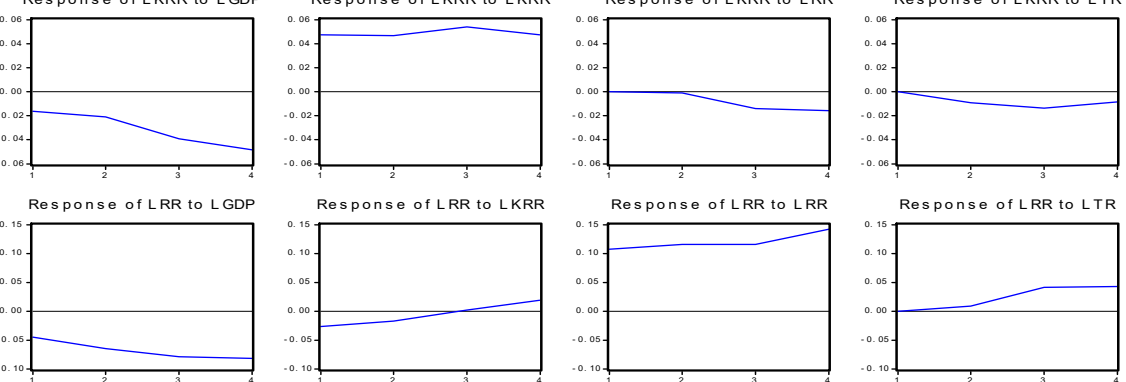

Response of LTR to LGDP
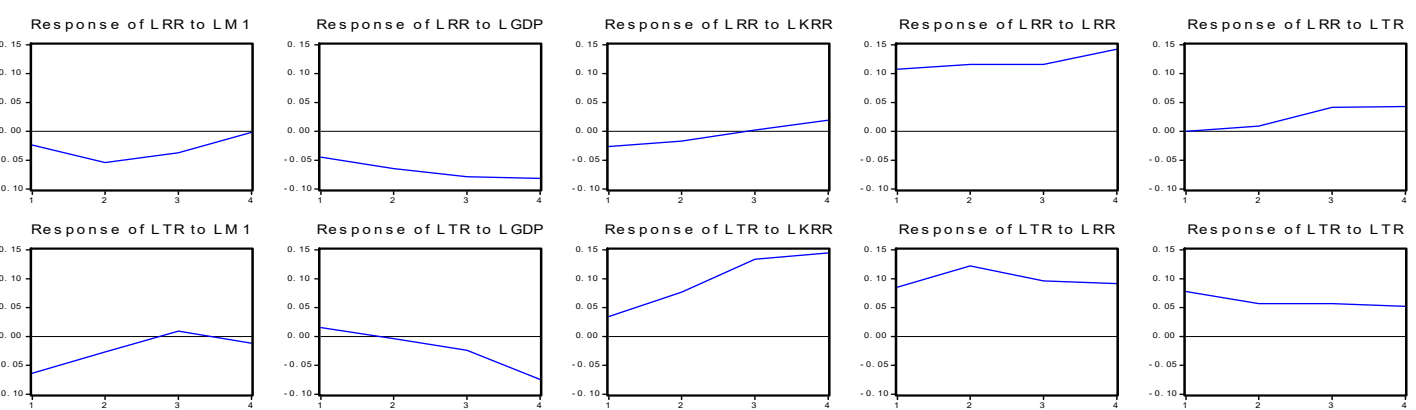

Figure 1. Impulse responses results

\section{Conclusion}

This paper has made an important finding that there is a long-run relationship among real money aggregates $\left(\mathrm{M}_{1}, \mathrm{M}_{2}\right.$ and $\left.\mathrm{M}_{3}\right)$, income measured as GDP, and short- and long-run interest rates in Rwanda over the period 2008Q3 to 2015Q4. The assessment of different combinations of variables provides supporting evidence for the popular claim that $\mathrm{M}_{1}$, the narrow definition of money, serves as the relatively better measure of the money aggregate than $\mathrm{M}_{2}$ and $\mathrm{M}_{3}$, when evaluating the stability of the money demand function. The long-term interest rate (LKRR) also seems to provide relatively better results than the short-term rate 
(LRR, and LTR) when we use broad money definition, $\mathrm{M}_{2}$, long term interest rate and short term interest rate coefficients were found insignificant this may be explained by lower development of money market in Rwanda and existence of excess liquidity in banking system of Rwanda (Note 3). Both the ECM and VECM for $\mathrm{M}_{1}$, narrow definition of money estimates showed the expected signs, in the ECM model as expected $\mathrm{LM}_{1}$ and LGDP were positively related while $\mathrm{LM}_{1}$ and LKRR, LRR, and LTR were negatively related. The adjustment coefficient in the ECM showed that about $79.75 \%$ of disequilibrium is corrected in each quarter. Impulse response functions suggest that the traditional money demand function, which places $\mathrm{LM}_{1}$ as its 'dependent' variable while including income and interest rates as its regressors, was stable with little responses model in the specific case of Rwanda over the period under review.

\section{References}

Asteriou, D., \& Hall, S. G. (2011). Applied Econometrics (2nd ed.). NYC: Palgrave Macmillan.

BNR. (2015). Quarterly Monetary Report: developments and outlook-2015 Q2. Retrieved from

http://www.bnr.rw/fileadmin/AllDepartment/MonetaryPolicy/upload/Quarterly/Moneta ryPolicyReports/QUARTERLY_MONETARY_REPORT_2015Q2.pdf

BNR Annual report. (2015, 2014, 2013, 2012, 2011,2010, 2009, 2008).

BNR economic review (2008). No 002, April, P. 42.

BNR economic review (2015). No 005, May.

BNR, economic review (2014). No 006, December.

BNR, economic review (2016). No 008, February.

Dickey, D. A., \& Fuller, W. A. (1981). Likelihood Ratio Statistics for Autoregressive Time Series with a Unit Root. Econometrica, 49(4), 1057-1072. http://dx.doi.org/10.2307/1912517

Doldado, J., Jenkinson, T., \& Sosvilla-Rivero, S. (1990). Cointegration and Unit Roots. $\begin{array}{llll}\text { Journal of Economic } & \text { Surveys, }\end{array}$ http://dx.doi.org/10.1111/j.1467-6419.1990.tb00088.x

Dwived, D. N. (2010). Macroeconomics: Theory and policy (3rd ed.). Tata McGraw hill, New Delhi, pp. 226-244.

Hyungsun, C., \& Miguel, D. R. (2016). Money Demand in Korea: A Cointegration Analysis.1973-2014 Department of Economics, Trinity College, Hartford, CT 06106.

Johansen, S., \& Juselius, K. (1990). Maximum Likelihood Estimation and Inference on Cointegration with Applications to the Demand for Money. Oxford Bulletin of $\begin{array}{llll}\text { Economics and } & \text { Statistics, }\end{array}$ http://dx.doi.org/10.1111/j.1468-0084.1990.mp52002003.x 
Keynes, J. M. (1939). The General Theory of Employment, interest and money. Cambridge: MacMillan. Retrieved from http://cas.umkc.edu/economics/people/facultypages/kregel/courses/econ645/winter201 $1 /$ generaltheory.pdf

Mankiw, N. G. (2008). Macroeconomics (6th ed.). Catherine woods and Craig Bleyer, 41 Madison Avenue, New York, NY 10010, P.82.

RYSB-Rwanda Statistical Year Book (2013). Glossary.

\section{Notes}

Note 1. Regarding the interest rates, the Central Bank rate of $9 \%$ was replaced by the Key Repo rate as "reference rate" and set at 8\% per annum from 8th August 2008. BNR, Annual Report, 2008.

Note 2. The OLS estimations and unit root test results for their residuals can be provided upon request.

Note 3. Rwanda banking sector has consistently experienced an important excess of liquidity as a result of an increase in public spending, especially owing to increases in aids inflows. During that period, the Central Bank monetary policy was mainly focused on managing the excess liquidity which was quite permanent in the banking system. BNR, economic review, No 005, May 2015.

\section{Appendixs}

\begin{tabular}{|c|c|c|c|c|}
\hline \multicolumn{5}{|c|}{ Dependent Variable: D(LM1) } \\
\hline \multicolumn{5}{|c|}{ Method: Least Squares } \\
\hline \multicolumn{5}{|c|}{ Date: $05 / 28 / 16$ Time: $13: 22$} \\
\hline \multicolumn{5}{|c|}{ Sample(adjusted): 2008Q4 2015Q4 } \\
\hline \multicolumn{5}{|c|}{ Included observations: 29 after adjusting endpoints } \\
\hline Variable & Coefficient & Std. Error & t-Statistic & Prob. \\
\hline $\mathrm{C}$ & 0.019776 & 0.015859 & 1.246972 & 0.2250 \\
\hline D(LGDP) & 1.098338 & 0.308649 & 3.558532 & 0.0017 \\
\hline $\mathrm{D}(\mathrm{LKRR})$ & -0.140536 & 0.233997 & -0.600591 & 0.5540 \\
\hline $\mathrm{D}(\mathrm{LRR})$ & 0.051809 & 0.102228 & 0.506801 & 0.6171 \\
\hline $\mathrm{D}(\mathrm{LTR})$ & -0.092906 & 0.084513 & -1.099313 & 0.2830 \\
\hline $\mathrm{E}(-1)$ & -0.797591 & 0.211106 & -3.778150 & 0.0010 \\
\hline R-squared & 0.467664 & \multicolumn{2}{|c|}{ Mean dependent var } & 0.041861 \\
\hline Adjusted R-squared & 0.351939 & \multicolumn{2}{|c|}{ S.D. dependent var } & 0.090734 \\
\hline S.E. of regression & 0.073043 & \multicolumn{2}{|c|}{ Akaike info criterion } & -2.213554 \\
\hline Sum squared resid & 0.122710 & \multicolumn{2}{|c|}{ Schwarz criterion } & -1.930665 \\
\hline Log likelihood & 38.09653 & \multicolumn{2}{|c|}{ F-statistic } & 4.041164 \\
\hline
\end{tabular}




\begin{tabular}{llll}
\hline Durbin-Watson stat & 2.307807 & Prob(F-statistic) & 0.008875
\end{tabular}

airwise Granger Causality Tests

Date: 05/28/16 Time: 18:34

Sample: 2008Q3 2015Q4

Lags: 2

\begin{tabular}{lcrc}
\hline Null Hypothesis: & Obs & F-Statistic & Probability \\
\hline LGDP does not Granger Cause LM1 & 28 & 0.74864 & 0.48419 \\
LM1 does not Granger Cause LGDP & & 3.13682 & 0.06243
\end{tabular}

Pairwise Granger Causality Tests

Date: 05/28/16 Time: 18:38

Sample: 2008Q3 2015Q4

Lags: 2

\begin{tabular}{lcrc}
\hline Null Hypothesis: & Obs & F-Statistic & Probability \\
\hline LKRR does not Granger Cause LM1 & 28 & 0.49002 & 0.61887 \\
LM1 does not Granger Cause LKRR & & 0.49788 & 0.61422 \\
\hline
\end{tabular}

Pairwise Granger Causality Tests

Date: $05 / 28 / 16$ Time: $18: 38$

Sample: 2008Q3 2015Q4

Lags: 2

\begin{tabular}{lccc}
\hline Null Hypothesis: & Obs & F-Statistic & Probability \\
\hline LRR does not Granger Cause LM1 & 28 & 3.32336 & 0.05397 \\
LM1 does not Granger Cause LRR & & 1.36663 & 0.27490
\end{tabular}

Pairwise Granger Causality Tests

Date: 05/28/16 Time: 18:39

Sample: 2008Q3 2015Q4

\begin{tabular}{lccc}
\hline Lags: 2 & & & \\
Null Hypothesis: & Obs & F-Statistic & Probability \\
\hline LTR does not Granger Cause LM1 & 28 & 0.65633 & 0.52820 \\
LM1 does not Granger Cause LTR & & 0.14767 & 0.86353 \\
\hline
\end{tabular}

\section{Copyright Disclaimer}

Copyright for this article is retained by the author(s), with first publication rights granted to the journal. This is an open-access article distributed under the terms and conditions of the Creative Commons Attribution license (http://creativecommons.org/licenses/by/3.0/). 